\title{
OPTIMALISASI PENDIDIKAN AGAMA ISLAM DI SEKOLAH
}

\begin{abstract}
Abstrak
Ely Manizar HM

Dosen Fakultas Ilmu Tarbiyah dan Keguruan UIN Raden Fatah Palembang

Kemajuan suatu bangsa hanya dapat dicapai melalui penataan pendidikan yang baik. Upaya peningkatan mutu pendidikan itu diharapkan dapat menaikkan harkat dan martabat manusia Indonesia, termasuk penataan pendidikan agama Islam. Tulisan ini dibuat dengan tujuan untuk mengkaji permasalahan pendidikan Agama Islam di sekolah dan mencoba memberikan solusi dalam mengoptimalisasikan pendidikan agama islam di Sekolah. Peningkatan mutu (kualitas) berarti penambahan pengetahuan, pembinaan skil, dan pengembangan keterampilan tentang pelaksanaan tugas mengajar sebagai guru. Dalam konteks zaman yang terus berubah, maka peningkatan kualitas menjadi suatu keniscayaan. Adapun yang layaknya diterapkan guna mencapai pengajaran dan kualias guru bidang pendidikan agama islam yang prima dilakukan langkah berikut : (1) Adanya kesetaraan sejawat di sekolah, (2) Sarana penunjang kegiatan, (3) Dukungan pihak terkait, (4) Menerapkan pengitegrasian Pendidikan Agama Islam, (5) Melakukan Evaluasi.
\end{abstract}

Kata Kunci: Profesionalisme, Guru, Pendidikan Agama Islam, Sekolah 


\section{PENDAHULUAN}

Pendidikan Agama Islam sebagai salah satu mata pelajaran di Sekolah umum sejak Sekolah Dasar (SD), sampai Terguruan Tinggi mempunyai peranan yang sangat strategis dan signifikan dalam membentuk peserta didik menjadi manusia yang beriman, berilmu dan berkepribadian muslim sejati, dalam UU Sistem Pendidikan Nasional menyatakan bahwa tujuan pendidikan adalah pemberdayaan potensi peserta didik agar menjadi manusia yang beriman dan bertaqwa kepada Tuhan Yang Maha Esa, berakhlak mulia, memiliki nilai dan sikap, sehat, berilmu, cakap, kreatif, mandiri dan menjadi warga Negara yang demokratis, bertanggung jawab. Untuk mewujukannya perlu perjuangan sungguhsungguh melalui lembaga-lembaga pendidikan. Sekolah umum merupakan salah satu lembaga pendidikan yang memiliki tanggung jawab dalam pembelajaran Pendidikan Agama Islam yang jumlah jam pelajaran 4 (empat) jam perminggu di SD dan 3 (tiga) Jam perminggu di SMP dan SMA/SMK, dimana.jumlah jam tersebut tidak menjamin sepenuhnya untuk dapat mewujudkan tujuan pendidikan Nasional, karena Materi pembelajaran Pendidikan Agama Islam sangat luas, kompleks dan universal.

Dalam kehidupan keseharian kita banyak sekali menemukan perilaku negatif yang ditunjukkan oleh peserta didik diantaranya tawuran, terlibat permerkosaan, hamil diluar nikah, perampokan, narkoba, pembunuhan dsb, Menurut Tafsir (1996: 21) ia mengatakan bahwa kemerosotan akhlak banyak terjadi pada semua lapisan masyarakat, akan tetapi dikalangan remaja lebih banyak, nyata dan terlihat, Perilaku tersebut merupakan indicator belum optimalnya pendidikan agama Islam di sekolah dan sekaligus tantangan bagi lembaga pendidkan khususnya guru pendidikan Agama islam untuk mencari model pembelajaran yang mampu menginternalisasikan nilai-nilai ajaran Islam dalam diri peserta didik. Dalam pandangan beberapa penulis bahwa setidaknya ada tiga alasan penting untuk mengoptimalkan pendidikan Islam di sekolah. Pertama, bahwa peserta didik aset terbesar umat Islam ada di sekolah, sebab jumlah generasi muda Islam di sekolah jauh lebih besar jika dibandingkan dengan generasi muda Islam di Madrasah atau Pesantren. 
Kedua, alokasi mata pelajaran PAI yang dilaksanakan di sekolah sangat terbatas yang tidak mungkin dapat menyelesaikan materi pembelajaran Agama Islam secara menyeluruh dan utuh. Dengan demikian, mata pelajaran yang diberikan lebih menekankan kepada materi khusus tentang ajaran Islam yang bersifat dogmatis. Bahkan tidak jarang guru PAI terjebak dalam penyampaian materi yang lebih menekankan pada aspek kognitif. Penanaman nilai-nilai keislaman dalam kehidupan sehari-hari tidak akan dapat dilakukan oleh guru PAI semata dengan alokasi waktu yang disediakan. Oleh karena itu optimalisasi PAI mesti dilakukan secara terpadu.

Ketiga, jika pendidikan Agama Islam kurang mendapat perhatian di sekolah, maka dikhawatirkan terjadinya dikotomi antara ilmu dan agama. Kelak mereka akan cerdas dan menguasai sains, akan tetapi tidak dilandasi dengan keimanan yang kuat, kaya intelektualitas tetapi miskin spiritualitas keagamaan. Akibatnya kecerdasannya lebih mendatangkan kemudratan dari pada kemaslahatan. Dan untuk mengatasi persoalan tersebut, perlu dilakukan optimalisasi pendidikan Islam di sekolah.

\section{PELAKSANAAN PENDIDIKAN AGAMA ISLAM DI SEKOLAH}

Pelaksanaan pendidikan agama Islam di sekolah masih menunjukkan keadaan yang memprihatinkan. Banyak faktor yang menyebabkan keprihatinan itu, antara lain pertama, dari segi jam pelajaran yang disediakan oleh sekolah secara formal, peserta didik dikalkulasikan waktunya hanya 3 jam pelajaran per minggu di tingkat SD dan 4 jam perminggu tingkat SMP/SMA untuk pendidikan agama . Coba bandingkan dengan mata pelajaran lainnya yang bisa mencapai 6 - 8 jam per minggu. Implikasinya bagi peserta didik adalah hasil belajar yang diperolehnya sangat minim dan terbatas. Sedangkan implikasi bagi guru itu sendiri adalah guru dituntut untuk melaksanakan kewajiban menyelenggarakan proses pembelajaran sebanyak 24 jam per minggu. Yang jadi persoalan adalah kalau seorang guru agama ditugasi mengajar di sekolah, misalnya di sekolah dasar (SD) ada 6 kelas kemudian di satu kelas guru mengajar 3 jam pelajaran, sehingga maksimal pembelajaran yang dilaksanakan guru adalah 18 jam pelajaran. Berarti guru tidak memenuhi kewajiban sesuai dengan tugas yang diberikan oleh 
pemerintah. Implikasinya adalah guru tersebut tidak berhak memperoleh tunjangan sebagai guru karena kewajiban mengajarnya belum memenuhi syarat yang sudah ditentukan oleh pemerintah. Tuntutan itu harus benar-benar diperhitungkan karena pemerintah memberikan dan menaikkan tunjangan bukan hanya gaji kepada guru yang melaksanakan tugas kewajibannya sesuai dengan jumlah jam pelajaran yang sudah ditentukan.

Pelaksanaan pendidikan agama Islam tidak hanya disampaikan secara formal dalam suatu proses pembelajaran oleh guru agama, namun dapat pula dilakukan di luar proses pembelajaran dalam kehidupan sehari-hari. Guru bisa memberikan pendidikan agama ketika menghadapi sikap atau perilaku peserta didik. Pendidikan agama merupakan tugas dan tanggung jawab bersama semua guru. Artinya bukan hanya tugas dan tanggung jawab guru agama saja melainkan juga guru-guru bidang studi lainnya. Guru-guru bidang studi itu bisa menyisipkan pendidikan agama ketika memberikan pelajaran bidang studi. Dari hasil pendidikan agama yang dilakukan secara bersama-sama ini, dapat membentuk pengetahuan, sikap, perilaku, dan pengalaman keagamaan yang baik dan benar. Peserta didik akan mempunyai akhlak mulia, perilaku jujur, disiplin, dan semangat keagamaan sehingga menjadi dasar untuk meningkatkan kualitas dirinya.

Kemajuan suatu bangsa hanya dapat dicapai melalui penataan pendidikan yang baik. Upaya peningkatan mutu pendidikan itu diharapkan dapat menaikkan harkat dan martabat manusia Indonesia.termasuk penataan pendidikan agama Islam. Pembelajaraan pendidikan agama Islam disekolah bukan menjadi tanggung jawab pembelajaran PAI semata, namun PAI merupakan mata pelajaran yang bertanggung jawab untuk mengembangkan keimanan, ketakwaan dan akhlak peserta didik sebagaimana yang diamanatkan oleh tujuan pendidikan nasional yang dimuat dalam penjelasan Undang-undang nomor 20 tahun 2003 tentang system pendidikan Nasional yaitu "pendidikan agama dinaksudkan untuk membentuk peserta didik menjadi manusia yang beriman dan bertakwa kepada Tuhan Yang Maha Esaserta berakhlak mulia” Untuk mencapai tujuan pendidikan agama itu, proses pendidikan dan peran lembaga-lembanga pendidikan sangat penting dan menempati kedudukan strategis, Kedudukan strategis itu telah 
menempatkan segenap pihaak yangterkait baik pada tingkat perencanaan, penyusunan program maupun pelaksanaan di lapangan harus adaptif terhadap perubahan.

Sebagaimana sudah diketahui bahwa pelaksanaan proses pendidikan itu masih dihadapkan pada berbagai hal, baik langsung maupun tidak langsung, baik berkaitan dengan hal-hal di dalam lembaga pendidikan maupun hal-hal di luar lembaga pendidikan sehingga pembentukan manusia yang beriman dan bertakwa belum berjalan mulus sebagaimana diharapkan, Itu semua menjadi tantangan yang harus diatasi kerena komitmen kebangsaan kita terhadap amanat konstitusional untuk memperjuangkan cita-cita nasional. Pembangunan manusia Indonesia yang beriman dan bertakwa harus barpacu keras dengan deras arus informasi dari berbagai sumber melalui berbagai media yang menjadi bagian tak perpisahkan dari proses globalisasi, berbagai kebijakan dan tindakan baanyak pihak, yang jelas-jelas bertantangan aatau tidak sejalan dengan nilai-nilai luhur yang disosialisasikan.

Dalam konteks pembaharuan pendidikan, ada tiga isu utama yang disoroti, yaitu pembaharuan kurikulum, peningkatan kualitas pembelajaran dan efektifitas metode pembelajaran khususnya pembaharuan di bidang Pendidikan Agama Islam. Pendidikan Agama Islam adalah upaya sadar, terencana dalam menyiapkan anak didik untuk mengenal, memahami, menghayati hingga mengimani, bertaqwa dan berakhlak mulia dalam mengamalkan ajaran Agama Islam dari sumber utamanya kitab suci Al Qur'an dan Al Hadits melalui bimbingan, pengajaran (Muhaimin, 2002: 75). Sedangkan fungsi pendidikan Agama Islam di sekolah adalah untuk pengembangan keimanan dan ketaqwaan kepada Allah serta akhlak mulia, penanaman nilai ajaran Islam sebagai pedoman mencapai kebahagiaan hidup di dunia dan akhirat, penyesuaian mental peserta didik terhadap lingkungan fisik dan sosial melalui pendidikan Islam. Berdasarkan fungsinya itu, maka tujuan pendidikan agama Islam di sekolah adalah untuk menumbuhkan dan meningkatkan keimanan, melalui pemberian dan pemupukan pengetahuan, penghayatan, pengamalan serta pengalaman peserta didik tentang agama Islam sehingga menjadi manusia muslim yang terus berkembang dalam hal keimanan, ketaqwaan kepada Allah serta berakhlak mulia dalam kehidupan pribadi, 
bermasyarakat, berbangsa dan bernegara, serta untuk dapat melanjutkan ke jenjang yang lebih tinggi.

Pendidikan Agama Islam (PAI) di sekolah yang sedang berlangsung belum semuanya memenuhi harapan kita sebagai umat Islam Misalnya kalau guru memberikan pendidikan agama Islam kepada peserta didik, maka tentu yang kita inginkan adalah peserta didik bukan hanya mengerti tetapi juga dapat melaksanakan praktek-praktek ajaran Islam baik yang bersifat pokok untuk dirinya maupun yang bersifat kemasyarakatan. Karena di dalam pendidikan agama Islam bukan hanya memperhatikan aspek kognitif saja, tetapi juga sikap dan keterampilan peserta didik. Hal ini sejalan dengan kebijakan umum Direktorat Jendral Pendidikan Agama Islam Departemen Agama yaitu peningkatan mutu khusus mengenai pendidikan agama Islam di sekolah, peningkatan mutu itu sendiri terkait dengan bagaimana kualitas hasil pembelajaran pendidikan agama Islam pada peserta didik yang mengikuti pendidikan di sekolah.

Penyelenggaraan pendidikan agama Islam di sekolah penuh tantangan, karena secara formal penyelenggaraan pendidikan Islam di sekolah waktunya sangat terbatas sehingga dalam menyampaikan materi pelajaran tidak dapat dilakukan secara terinci dan mendalam dan tidak dapat sepenuhnya memenuhi rana kognitif afektif dan psikomotorik. Jika sebatas hanya memberikan pengajaran agama Islam yang lebih menekankan aspek kognitif, mungkin guru bisa melakukannya, tetapi kalau memberikan pendidikan yang meliputi ketiga rana tersebu guru akan mengalami kesulitan. Untuk mengatasi kekurangan waktu belajar pendidikan Agama Islam salah satu cara yang bisa ditempuh guru yaitu menambah pembelajaran pendidikan agama Islam melalui pembelajaran ekstra kurikulerl, memberikan tugas-tugas tertentu serta untuk menjalin kerjasama dengan orang tua dan pihak-pihak tertentu guna membantu peserta didik dalam menguasai dan mendalami nilai-nilai ajaran agama yang diberikan oleh guru.

\section{GURU PENDIDIKAN AGAMA ISLAM}

Gambaran umum tentang mutu pendidikan agama Islam di sekolah belum memenuhi harapan-harapan dalam peningkatan kualitas pendidikan agama Islam di sekolah yang menjadi agama sebagai benteng moral bangsa. Kondisi ini 
dipengaruhi oleh salah satu factor yaitu sumber daya guru. Guru pendidikan agama Islam dibanyak tempat sering kali merasa bagaikan a single singhter di tengah medan yang luas, mereka dihadapkan pada keadaan dan suasana yang memang belum mendukung untuk menunaikan tugas dan tanggung jawab pengabdiannya. Mereka acapkali tidak menemukan mitra yang dapat berjuang bahu membahu dalam menunaikan amanah kebangsaan. Keadaan seperti ini diperparah lagi oleh penampilan guru PAI yang tidak sedikit yang berada dibawah mutu baku. Mereka terkesankan puas hanya dengan menyampaikan sejumlah pengetahuan tentang al Islami yang mencakup kegiatan hanya sebatas apa yang digariskan dalam GBPP. dimana mereka belum terpanggil untuk bertugas bukan hanya sebatas menyampaikan apa yang tertulis dalam silabus.

Pada hal pengertian pendidikan agama Islam sebaagaimana diuraikan terdahulu membawa konsekuensi dan tanggung jawab yang lebih luas pada guru PAI, yaitu berperan sebagai ujung tombak dalam mengajari, ,menuuntun, mengarahkan dan membiasaakan peserta didik mengamalkan ajaran agama di lingkungan sekolah. Guru PAI seharusnya tampil menunaikan tugasnya bukan semata-mata didasarkan atas formalitas kewajibannya, melainkan didorong oleh yang pertaama-tama panggilan jiwa dan kesadaran nurani muslimnya untuk menyampaikan dan mengahadirkan Al-Islam lebih banyak dan lebih baik. Untuk itu diperlukan upaya dan usaha nyata melalui program terpadu untuk meningkatkan jumlah dan mutu guru PAI di semua jenis dan jenjang pendidikan. Pengetahuan dan ketrampilan metodologis-teknologis, media pembelajaran dengan menggunakan IT harus dilakukan, disamping melalui usaha sendiri perlu ditingkatkan wawasan dan pengalaman mereka perlu diperkaya sehingga mereka tidak terlalu ketinggalan kereta dibandingkan dengan teman sejawat yang lain.

Menurut Arifin (2000) Guru di Indonesia dipersyaratkan mempunyai: (1) Dasar ilmu yang kuat sebagai pengejawantahan terhadap teknologi dan ilmu pengetahuan. (2) Penguasaan kiat-kiat profesi berdasarkan riset dan praksis pendidikn yaitu ilmu pendidikan sebagai ilmu praksis bukan hanya merupakan konsep-konsep belaka. Pendidikaqn merupakan proses yang terjadi di lapangan dan bersifat ilmiah serta riset pendidikan hendaknya diarahkan pada praksis pendidikan masyarakat Indonesia. (3) Pengembangan kemampuan professional 
berkesinambungan, profesi guru merupakan profesi yang berkembang terus menerus dan berkesinambungan antara LPTK dengan praktek pendidikan. Oleh karenanya Penugasan studi banding ke luar daerah dan bahkan ke luar negeri perlu dilakukan sebagai salah satu contoh program peningkatan dan memperluas wawasan, dan masih banyak lagi bentuk-bentuk kegiatan pembelajaran yang lainnya. Dengan begitu tuntutan terhadap guru PAI agar memaksimalkan penunaian tugasnya di sekolah melalui pengayaan dan penganekaragamaan kegiatan pendidikan agama di satu sisi dan pada sisi lain diimbangi dengan peningkatas pengetahuan dan wawasan mereka secara proporsional. Diharapkan kreatifitas dan kemampuan inovatif mereka dapat ditingkatkan seiring dengan kemajuan dantantangan yang kian bertambah.

Pendidikan mutu guru sebagai pendidik dan tenaga kependikan dilaksanakan dengan mengacu pada standar pendidik dan tenaga kependidikan mata pelajaran dalam Standar Nasional Pendidikan (SNP). Untuk itu dilakukan kegiatan-kegiatan penyediaan guru pendidikan agama Islam untuk satuan pendidikan peserta didik usia dini, pendidikan dasar, pendidikan menengah, dan pendidikan tinggi pada jalur formal dan non formal, serta informal. Dilakukan pula pendidikan dan pelatihan metode pembelajaran pendidikan agama Islam, pemberian bea peserta didik Strata 1 (S1) untuk guru pendidikan agama Islam, dan juga melakukan sertifikasi guru pendidikan agama Islam.

Ada dua jalur/cara dalam rangka peningkatan kualitas kemampuan guru, pertama adanya jalur resmi untuk mengikuti pendidikan S1, kedua yang rutin mengikuti kegiatan-kegiatan melalui Musyawarah Guru Mata Pelajaran (MGMP). Dari kedua jalur ini, diharapkan guru pendidikan agama Islam di sekolah tidak berjalan begitu saja dan kemampuannya juga tidak meningkat. Sebagai orang Islam kita berpegang kepada suatu kaidah yang menyatakan bahwa kalau hari ini lebih jelek dari hari kemarin, maka celaka. Kalau hari ini sama dengan hari kemarin, maka rugi, dan kalau hari ini lebih bagus dari hari kemarin, maka beruntung. Maka harus ada upaya-upaya untuk terus menerus belajar minal mahdi ilallahdi. Dalam salah satu hadits dinyatakan bahwa jadilah kalian orang yang mengajar, atau jadilah orang-orang belajar atau kalau tidak kedua-duanya sekurang-kurangnya mendengarkan. Janganlah jadi yang keempat yaitu tidak 
mengajar, tidak belajar, dan tidak mendengar. Untuk itulah guru yang harus selalu meningkatkan kualitas dirinya.

\section{UPAYA OPTIMALISASI PENDIDIKAN AGAMA ISLAM DI SEKOLAH}

Di dalam UUD 1945 menyatakan bahwa setiap warga Negara Indonesia harus memperoleh pendidikan yang baik dan berkualitas untuk dapat mewujudkan kecerdasan kehidupan bangsa Indonesia kedepan. Konstitusi telah mengamanatkan agar pembiayaan pendidikan sekurang-kurangnya $20 \%$ dari APBN dan APBD. Ini menunjukkan bahwa Negara secara serius menempatkan sector primadona dalam pembangunan nasional. Belajar dari Negara-negara lain yang sudah lebih dulu mencapai kemajuan, hampir semuanya menempatkan pendidikan sebagai leadin-sector pembangunan untuk dapat mengahasilkan sumber daya manusia (SDM) bermutu yang akan menjadi pengelola pembangunan bangsanya. Dengan pendanaan yang memadai, maka perbaikan pendidikan termasuk pendidikan Agama Islam didalamnya yang dimulai dengan mutu guru yang ditingkatkan, perbaikan sarana dan prasarana belajar, kesejahteraan guru, perbaikan kurikulum sampai dengan penyediaan buku pelajaran yang terjangkau oleh semua lapisan masyarakat.

Pendidikan agama yang dilaksanakan disekolah merupakan bagian yang integral untuk mencapai tujuan pendidikan nasional. Menurut Undang-Undang nomor 20 tahun 2003 tentang pendidikan nasional Pasal 1 merupakan usaha sadar dan terencana untuk mewujudkan suasana belajar dan proses pembelajaran agar peserta didik secara aktif mengembangkan potensi dirinya untuk memiliki kekuatan spiritual keagamaan, pengendalian diri, kepribadian, kecerdasan, akhlak mulia, serta ketrampilan yang diperlukan dirinya, masyarakat, bangsa dan negara. Pendidikan agama Islam sering disebut pendidikan agama yang dilaksanakan sejak sekolah dasar sampai perguruan tinggi selama ini secara kuantitatif telah menyumbang tidak kecil terhadap peningkatan kehidupan keagamaan. Pendidikan agama merupakan komponen materi dasar yang wajib disajikan pada semua jenjang pendidikan. Dalam Undang-Undang No. 2 Tahun 1989 Pasal 39 ayat 2 di dalamnya menjelaskan bahwa undang-undang telah mengikat semua orang untuk memperoleh pendidikan agama secara layak dan memadai sehingga secara 
formal-legal setiap orang yang mengenyam pendidikan mengalami proses pembentukan sebagai manusia beriman dan bertaqwa kepada Tuhan Yang Maha Esa.

Namun demikian tidak berarti bahwa pelaksanaan pendidikan agama itu telah memenuhi keseluruhan cita-cita kebangsaan kita. Dalam keyataan tilikan amatan penulis bahwa pendidikan agama Islam belum sepenuhnya berlangsung pada alur yang mampu mengantarkan peserta didik pada pengamalan nilai-nilai yang terdapat dalam ajaran al-islam. Pendidikan agama belum sepenuhnya diarahkan pada proses pembentukan yang komprehensip sebagai makna dari pendidikan Islam itu sendiri. Pendidikan agama seperti ditegaskan (Hasan Walinono: 1991) memang tidak hanya berlaku sebagai mata pelajaran yang menyangkut rana kognitif belaka, tetapi dengan meminjam istilah (Bloom:1956) sekaligus dan serentak menyentu rana afektif dan psikomotorik berupa penghayatan dan pengamalan agama. Itu berarti bahwa pendidikan agama bukan semata-mata dan selesai pada penyampaian pengetahuan tentang al-islam, melainkan melatih dan menuntun pengamalan apa yang diajari dan menciptakan suasana keagamaan dalam lingkungan sekolah. Kedudukan pendidikan agama pada dasarnya menjadi prominent dan pusat dalam pelaksanaan pendidikan untuk membentuk manusia yang beriman dan bertaqwa kepada Tuhan Yang Maha Esa dan bukan menjadi pinggiran (Peripheral) tidak sedikit orang yang memandang dan memperlakukan pendidikan agama sebagai irritant, sesuatu yang menjadi penghalang atau pengganggu kelancaran penguasaan pengetahuan dan pencapaian akademik. Pendidikan agama sering dipandang sebagai sesuatu yang tidak memiliki daya paksa dalam proses pendidikan secara keseluruhan, sehingga diremehkan. Ini tentu merupakan sesuatu yang eronis dalam perjuangan menuju cita-cita dan tujuan pendidikan nasional kita. Oleh karena itu optimalisasi pendidikan agama harus dilakukan dengan mengoptimalkan fungsinya dan memaksimalkan program dan kegitannya dengan upaya-upaya sebagai berikut:

1. Kesetaraan sejawat di sekolah

Dalam pelaksanaan kegiatan pembelajaran pendidikan agama akan berhasil dengan baik manakala adanya kerjasama dengan semua pihak yang terkait diantaranya sejawat yaitu guru-guru di tiap sekolah, dimana mereka ini adalah 
sejawat dan mitra guru PAI. Setiap guru sesungguhnya memikul amanah dan tanggung jwab untuk memperjuangkan tercapainya tujuan pendidikan nasional sekalipun tanggung jawab formal dan pembidangan tugas dibedakan. Pelaksanaan pendidikan agama memerlukan dukungan dari semua pihak. Ujung tombak dan penanggung jawab formal pendidikan agama di sekolah adalah guru pendidikan agama. Namun itu tidak berarti bahwa guru-guru lain tidak terkait dengan proses pendidikan yang bertujuan menjadikan peserta didik manusia-manusia yang beriman dan bertakwa kepada Tuhan Yang Maha Esa.

Tiap guru memikul tanggung jawab moral untuk mendukung baik langsung maupun tidak langsung, baik secara perorangan maupun secara lembaaga-Corps terselenggaranya proses pendidikan agama yang memang tidak hanya terbatas di dalam penyajian mata pelajaran dalam kelas. Phail (1982:124) mengatakan bahwa sampai kapanpun guru akan menjadi factor penting dalam proses pendidikan. Diperkuat oleh pendapat Vaizey (1978:23) kehadiran guru tidak dapat digantikan oleh mesin-mesin yang dapat diciptakan oleh teknologi modern. Oleh karena itu dalam hal inipun guru memang diharapkan benar kesertaannya sebagai menifestasi tanggung jawabnya sebagai ujung tombak proses pendidikan di sekolah. Apalagi bila di suatu sekolah dikembangkan oleh guru pendidikan agama berbagai kegiatan yang berusaha membimbing dan membiasakan peserta didik mengamalkan nilai-nilai agama, maka kemitraan para guru semakin dibutuhkan untuk mendukungnya. Pada dasarnya setiap guru wajib memberikan dukungan pada segenap program dan kegiatan yang merupakan penjabaran kreatif untuk mencapai tujuan pendidikan nasional. Wanono (1991:5) menegaskan bahwa para guru di bawah tanggung jawab kepemimpinan kepala sekolah berkewajiban memelihara dan meningkatkan suasana kehidupan keagamaan di tempat ia bertugas. Penganeka ragaman kegiatan oleh guru pendidikan agama tidak akan berjalan lancar tanpa didukung oleh keseluruhan corps guru di suatu sekolah. Kemitraan corps guru dalam menunjang kegiatan pendidikan agama pada awalnya tergantung pada pendekatan yang dilakukan oleh guru pendidikan agama di samping didukung oleh kepala sekolah. Diperlukan kegesitan, kesungguhan dan penampilan guru pendidikan agama untuk menarik simpati para sejawat, agar program kegiatan memperoleh dukungan yang sesungguhnya sehingga para guru 
merasa bahwa yang dilakukan oleh guru pendidikan agama juga merupakan bagian dari tugas yang ia pikul. Perlu disingnggung pula bahwa peran kepemimpinan kepala sekolah dalam meningkatkan kegiatan pendidikan agama islam sangat diperlukan,dimana kepala sekolah berdasarkan kewenangan yang dimilikinya dapat memberikan pimpinan, arahan dan penyadaran kepada teman sejawat tentang arti tugas dan tanggung jawab guru dalam menunjang pencapaian tujuan pendidikan dan sekaligus kesertaan yang aktif di dalamnya. Dalam hal ini figure kepala sekolah akan banyak menentukan sukses tidaknya program guru pendidikan agama Islam.

2. Sarana penunjang kegiatan

Melengkapi sarana pembinaan agama Islam di sekolah. Untuk mendukung kegiatan pendidikan Islam di sekolah, Pendidikan agama memerlukan sarana penunjang yang akan memungkinkan kegiatan-kegiatannya dapat dilaksanakan. Sarana yang dimaksud berupa sumber belajar seperti buku-buku yang memadai, sarana labor agama dengan menyiapkan perlengkapan yang menunjang materi pembelajaran, seperti perlengkapan shalat, peralatan shalat jenazah, peralatan ibadah haji, peralatan thaharah, contoh jenis-jenis binatang halal dan haram, dan sebagainya. Labor tersebut juga dilengkapi dengan multimedia, seperti computer, infocus, dan sound system sehingga CD pembelajaran PAI kesemuanya akan diperuntukkan bagi peserta didik guna mendalami pengetahuan dan ketrampilan keagamaan. Apalagi bila peningkatan kegiatan-kegiatan pendidikan agama akan diwujudkan, maka pengadaan sarana penunjang itu menjadi keharusan yang mendesak. Ini semua tentu harus diatasi semua pihak yang terkait baik pelaksana di lapangan maupun penentu kebijakan di atasnya dan para orang tua serta masyarakat pada umumnya kare4na hal ini adalahbtanggung jawab bersama.

3. Dukungan pihak terkait.

Apa yang dijelaskan di atas bermuara pada tanggung jawab kita semua terutama dukungan kebijaksanaan dan pengaturan structural dari semua lini dan lapisan. Kita mengharapkan tumbuhnya gagasan-gagasan dan rencana-rencana kegiatan nyatadari bawah, yaitu dari para guru dan sekolah masing-masing. Numun itu perlu didukung oleh peraturan kebijaksanaan yang lebih kokoh dari atas dan masyarakat luas agardapatterlaksana dengan baik. Langkah-langkah yang 
ditempuh, kebijaksaan yang diambil, program aksi yang dilaksanakan merupakan bagian dari perjuangan besar untuk membangun masa depan yang lebih baik, manusia dan masyarakat Indonesia yang tangguh menghadapi tantangan kehidupan yang kian kompleks pada masa depan. Itu akan tergantung pada usaha, kebijaksanaan, pelaksanaan tugasyang dilakukan padahari ini. Dengan mengutif pendapat Sardar (1989:12) bahwa pilihan-pilihyan strategis dan bermakna yang kita ambil sekarang ini akan menggambarkan corak masa depan apa yang akan kita hadirkan, karena masa depan merupakan hasil perjuangan kitahari ini.

Untuk itu diperlukan ketulusan masyarakat luas untuk menunjang kemauan parapemegang kekuasaan dan pengambil kebijasanaan, kreatifitas dan keberanian serta kesungguhan paraguru dan kepala sekolah. Semua itu saling terkaitdan member sumbangan yang saling mengisi dan saling mendukung, bias saja suatu sekolah suatu sekolah memiliki kemampuan mengembangkan dan meningkatkan kegiatan, tapi tidak dapat ditularkan ke sekolah lain tanpa didukung oleh keputusan pihak berwenang. Dalam hubungan ini perlu diperhatikan dan di ingat bahwa di dalam suasana masyarakat kita yang masih lebih cenderung bersifat paternalistic, peran pengarahan dan keputusan resmi dari atas akan sangat berpengaruh terhadap suatu program. Gagasan atau kegiatan yang tersifat Bottom up tumbuh dari bawah masih sulit dipopulerkan tanpa lagalisasi dari atas. Sebaliknya program yang digariskan dari atas top down memang mempunyai dasar dan daya pemaksa lebih besar sehingga secara merata dan serentak dapat dilaksanakan.

4. Menerapkan pengintegrasian Pendidikan Agama Islam (PAI) ke dalam mata pelajaran umum.

Program ini sebenarnya telah dilakukan sejak pada tahun 1994 dengan program PWKG lalu dikembangkan menjadi program peningkatan Imtaq atau dikenal juga dengan integrasi IMTAQ dan IPTEK. Namun sejak awal tahun 2000, program ini tidak lagi diterapkan dan mendapat perhatian dari pemerintah. Padahal upaya mengintegrasikan PAI ke dalam mata pelajaran umum akan menghilangkan dikotomi antara ilmu dan agama. Peserta didik juga akan mampu memahami dan merasakan bahwa semua ilmu berasal dari Allah sehingga kelak ia menjadi 'alim (orang yang berilmu) dan dekat dengan al-'Alim (Yang Maha 
Mengetahui). Jadi pemerintah daerah diharapkan membentuk tim untuk mendesain kurikulum setiap mata pelajaran umum dengan corak terintegrasi PAI. Adapun kesulitan guru-guru umum dalam mengintegrasikan PAI tersebut dapat diatasi dengan menyusun panduan yang lebih jelas serta mengadakan pelatihanpelatihan secara berkelanjutan dan terorganisir.

\section{Melakukan Evaluasi}

Mengenai evaluasi pendidikan agama Islam ini terkadang terjadi hal-hal yang di luar dugaan. Misalnya ada peserta didik yang jarang sekolah, malas dan merasa terpaksa mengikuti pelajaran agama, tetapi ketika dievaluasi dia mendapatkan nilai yang lebih tinggi dibandingkan dengan peserta didik yang rajin belajar agama. Artinya yang salah itu adalah evaluasinya karena yang dilakukan hanyalah mengukur unsur kognitifnya saja. Oleh karena itu evaluasi pendidikan agama Islam jangan hanya mengandalkan evaluasi kemampuan kognitif saja, tetapi harus dievaluasi juga sikap, prakteknya atau keterampilan (psikomotor) dan sikapnya (afektif). Evaluasi ini sebetulnya menentukan status peserta didik tentang hasil belajarnya itu apakah sudah mencapai tujuan yang ingin dicapai atau tidak. Kalau tujuan agama itu adalah supaya peserta didik bisa menjalankan agama Islam dengan baik maka evaluasinya harus sesuai, dan evaluasinya itu bukan hanya hafal tentang kaidah-kaidah tentang kemampuan kognitif saja tetapi juga yang bersifat praktikal.

Berkaitan dengan evaluasi pendidikan agama Islam, ada usulan yang kuat dari berbagai kalangan agar pendidikan agama Islam sebaiknya masuk pada ujian nasional, sehingga menjadi bahan untuk dipertimbangkan peserta didik lulus atau tidak lulus di suatu lembaga pendidikan. Ujiannya jangan sekedar mengukur kemampuan kognitif melainkan juga kemampuan yang bersifat psikomotor, praktek dan perilaku, serta sikap peserta didik sebagai orang yang menganut ajaran agama Islam. Namun, dalam pelaksanaan program pedidikan agama di berbagai sekolah di indonesia, belum berjalan seperti yang di harapkan, karena berbagai kendala dalam bidang kemampuan pelaksanaan metode, sarana fisik dan nonfisik, di samping suasana lingkungan pendidikan yang kurang menunjang suksesnya pendidikan mental-spiritual dan moral. 


\section{PENINGKATAN MUTU PROFESIONALISME GURU PAI}

Islam sebagai ajaran dan pedoman hidup universal sesungguhnya sangat memperhatikan mutu, dalam kehidupan umat di dunia dan di akhirat. Dalam konteks ini, suatu "mutu" dicirikan dari pemenuhan harapan pelanggan, atau mutu diaplikasikan atas produk, pelayanan, orang, proses, dan lingkungan, sehingga dipahami bahwa kualitas merupakan satu pernyataan perubahan yang terjadi. Untuk menjalankan peran strategis guru PAI maka diperlukan ketersediaan guru PAI yang professional. Untuk mengajarkan mata pelajaran agama, tentu saja harus diserahkan kepada orang-orang yang ahli dalam bidang pendidikan agama Islam. Inilah praktik pendidikan agama Islam professional, yang dilaksanakan oleh guru yang ahli merencanakan, melaksanakan dengan strategi, memimpin siswa dengan keteladanan, dan mengevaluasi proses pembelajaran PAI.

Profesi adalah suatu pekerjaan atau jabatan yang menuntut keahlian tertentu. Artinya suatu pekerjaan atau jabatan yang disebut profesi tidak dapat dipegang oleh sembarang orang, tetapi memerlukan persiapan melalui pendidikan dan pelatihan secara khusus. Professional adalah pekerjaan atau kegiatan yang dilakukan oleh seseorang dan menjadi sumber penghasilan kehidupan yang memerlukan keahlia, kemahiran, atau kecakapan yang memenuhi standar mutu atau norma tertentu serta memerlukan pendidikan profesi. Karena itu, sejak tahun ini sudah dimulai seterusnya ke depan, seorang sarjana pendidikan sebagai calon guru wajib mengikuti pendidikan profesi guru (PPG) satu tahun supaya mendapat sertifikat pendidik professional sebagai syarat profesi melakukan tugas dan jabatan mengajar.

Itu artinya profesi adalah kedudukan atau jabatan yang memerlukan ilmu pengetahuan dan keterampilan khusus yang diperoleh melalui pendidikan atau perkuliahan yang bersifat teoretis dan disertai praktek, diuji dengan berbagai bentuk ujian di universitas atau lembaga yang diberi hak untuk dan diberikan kepada orang-orang yang memilikinya (sertifikat, lisensi, brafet) suatu kewenangan tertentu dalam hubungannya dengan kliennya yang dipelihara dengan hati-hati dan selalu ditingkatkan melalui organisasinya. Di sini dipahami bahwa profesi adalah suatu pekerjaan yang didasarkan kepada pendidikan dan pelatihan khusus dengan tujuan memberikan layanan dengan keahliannya kepada orang lain 
dengan imbalan dan gaji tertentu. Pekerjaan atau jabatan itu dilaksanakan seseorang apabila dia telah mendapatkan ijazah tertentu sehingga tidak sembarangan orang dapat melakukan pekerjaan tersebut. Demikian halnya pekerjaan yang dikategorikan profesi seperti dokter, pengacara, akuntan, bidan, guru dan lain sebagainya.

Ada beberapa alasan rasional dan empirik sehingga tugas mengajar disebut sebagai profesi, yaitu: (1) Bidang tugas guru memerlukan perencanaan yang matang, pelaksanaan mantap dan pengendalian yang baik. Tugas mengajar dilaksanakan atas dasar sistem, (2) Bidang pekerjaan mengajar memerlukan dukungan ilmu teoritis pendidikan dan mengajar, (3) Bidang pendidikan ini memerlukan waktu lama dalam masa pendidikan dan latihan, sejak pendidikan dasar sampai pendidikan tinggi untuk pendidik dan tenaga kependidikan.

Kedudukan guru yang diyakini sangat strategis, yaitu: (1) Agen pembaharuan, (2) Berperan sebagai fasilitator yang menciptakan kondisi belajar dalam diri anak, (3) Bertanggung jawab atas terciptanya hasil belajar subjek didik, (4) Sebagai contoh teladan, (5), Bertanggung jawab secara profesional meningkatkan kemampuannya, (6) Menjunjung tinggi kode etik profesional. Berkaitan dengan penjelaskan di atas, maka karakteristik profesi dapat disimpulkan yaitu : (1) Jabatan yang memerlukan pendidikan yang panjang dan menyangkut pengetahuan dan keterampilan khusus, (2) adanya sistem ujian yang berkaitan dengan kemampuan teoritis dan praktek sehingga benar-benar memiliki otoritas dan kewenangan dalam tugasnya, (3) Adanya organisasi profesi yang memelihara kepentingan, kewenangan dan mutu profesi, (4) Adanya kode etik dan sumpah jabatan yang menjadi pegangan anggota profesi dalam bertugas, (5) Adanya standar pengetahuan dan keterampilan khusus yang terus dipelihara, dikembangkan dan membedakannya dari profesi lain.

Menurut Bestor, kualifikasi utama profesi, yaitu: (1) Memiliki ilmu pengetahuan yang luas dalam bidang yang dikerjakan, (2) Memiliki kemampuan dan keterampilan dalam melaksanakan pekerjaannya sesuai, bidangnya, (3) Memiliki karakter atau kepribadian yang membuat nya dihargai, dibanggakan dan diterima kliennya. Profesionalisme berasal dari kata profesi. Istilah profesi menurut Arifin, berasal dari kata Profesion mengandung arti sama 
dengan occupation yaitu suatu pekerjaan yang memerlukan keahlian yang diperoleh melalui pendidikan atau latihan khusus. Menurutnya profesi sebagai bidang keahlian yang khusus untuk menangani lapangan pekerjaan tertentu yang membutuhkannya. Profesionalisme merupakan paham yang mengajarkan bahwa setiap pekerjaan harus dilakukan oleh orang yang professional. Sesungguhnya orang yang professional adalah orang yang memiliki profesi.

Pembelajaran merupakan proses menyiapkan lingkungan yang memungkinkan anak untuk melakukan pembelajaran dalam rangka mencapai perubahan perilaku. Untuk mengaplikasikan tugas-tugas pembelajaran lebih kreatif, sehingga tercapai tujuan atau sasaran yang diharapkan dalam proses pembelajaran maka setiap guru sangat dituntut untuk memiliki kompetensi dalam proses pembelajaran. Kompetensi merupakan salah satu kualifikasi guru yang terpenting. Bila kompetensi itu tidak ada pada diri seorang guru, maka ia tidak memiliki kompetensi dalam melaksanakan tugas guru di lembaga pendidikan formal. Sebab guru harus dapat memenuhi kompetensi yang diharapkan oleh masyarakat dan anak didik dalam melaksanakan pendidikan dan pembelajaran. Begitu pula, dengan kompetensi itu guru dapat mengembangkan karirnya sebagai guru yang baik, sehingga ia dapat mengatasi berbagai kesulitan dalam proses pembelajaran. Di samping itu ia akan mengerti dan sadar akan tugas dan kewajibannya sebagai pendidik yang baik dan didambakan oleh masyarakat.

Profesionalisme dalam bidang pendidikan merupakan seperangkat tugas dan fungsi dalam lapangan pendidikan berdasarkan keahlian. Para guru yang profesional memiliki kompetensi keguruan berkat pendidikan atau latihan di lembaga pendidikan guru dalam jangka waktu tertentu. Misi profesional disimpulkan dalam tiga dimensi utama, yaitu: pengetahuan, keterampilan dan komitmen. Pelaksanaan tugas guru yang mengacu kepada tiga dimensi tadi menurut Arifin, mencakup kriteria dasar yaitu: kepribadian guru, penguasaan ilmu yang diajarkan dan keterampilan mengajar. Selanjutnya profesionalisme guru yaitu:

a. Kepribadian guru yang unik dapat mempengaruhi murid yang dikembangkan terus menerus sehingga ia benar-benar terampil (1) memahami dan menghargai setiap potensi murid (2) Membina situasi sosial 
yang meliputi interaksi belajar mengajar mendorong murid dalam meningkatkan kemampuan memahami pentingnya kebersamaan dan kesepahaman arah pemikiran dan perbuatan di kalangan murid (3) Membina perasaan saling mengerti, saling menghormati dan saling bertanggung jawab dan percaya mempercayai antara guru dan murid.

b. Penguasaan ilmu pengetahuan yang mengarah pada spesialisasi ilmu yang diajarkan kepada murid.

c. Keterampilan dalam mengajarkan bahan pelajaran terutama menyangkut perencanaan program, satuan pelajaran dan menyusun seluruh kegiatan untuk satu mata pelajaran menurut waktu.

Perubahan yang cepat berimplikasi terhadap nilai-nilai yang diyakini masyarakat. Ini merupakan tantangan para guru pendidikan agama Islam. Dalam menentukan nasib bangsa di masa depan maka peranan guru pendidikan agama Islam tidak bisa diabaikan, sebab para guru merupakan ujung tombak bagi keberhasilan pendidikan dan pengajaran di setiap sekolah. Konsekuensinya adalah bahwa untuk keberhasilan program pendidikan agama Islam mutlak diperlukan ketersediaan guru pendidikan agama Islam yang profesional. Peranan guru-guru yang profesional ini penting sekali dalam menuntun proses pendidikan agama Islam sehingga nilai-nilai ajaran agama Islam benar-benar mantap sejak dari pendidikan dasar sebagai bekal hidup anak menghadapi perubahan zaman yang cepat. Sebab nilai-nilai universal sajalah yang dapat membimbing anak dalam cepatnya perubahan zaman. Di sini diperlukan peningkatan mutu profesionalisme guru PAI yang sangat berperan strategis membina anak didik.

Mutu seseorang atau sesuatu nampak dalam konteks berhadapan dengan lawan/kompetitor. Berdasarkan kepada pernyataan Allah, bahwa yang sedikit dapat mengalahkan yang banyak karena kualitasnya. Ayat yang menceritakan pertarungan Thalut - raja Bani Israil dengan balatentara 80.000 orang berhadapan melawan Jaluth. Mereka diuji Allah untuk menyeberangi suangai padahal musuh lebih besar. Hanya sebagian kecil saja yang mau menyeberang dengan dorongan ulamanya karena yakin akan janji Allah, dan kemenangan bukan karena banyak tentara namun karena izin Allah. Akhirnya tentara Thalut mampu mengalahkan Jalut dalam peperangan tersebut, karena kualitas tentaranya. Dalam konteks 
pendidikan Islam sangat jelas pernyataan Allah SWT, bahwa tidak sama kedudukan orang yang berilmu dengan yang tidak berilmu pengetahuan. Karena itu, orang yang berilmu (ya'lamun) juga harus beriman dan bertaqwa serta berbuat baik di dunia dibarengi kesabaran, ikhlas, menuju muslim sejati. Dalam Shihab, dijelaskan bahwa siapa yang memiliki pengetahuan-apapun pengetahuan itu pasti tidak sama dengan orang yang tidak mengetahui, atau tidak memiliki pengetahuan. Namun ilmu pengetahuan yang dimaksud di sini adalah pengetahuan yang bermanfaat, yang membuat seseorang mengetahui hakikat sesuatu lalu menyesuaikan diri dan amalnya sesuai dengan pengetahuannya.

Dalam perspektif Islam bahkan kedudukan orang yang berilmu dan beriman ditinggikan Allah dari yang lain. Karena fungsi ilmu dapat meningkatkan keimanan seseorang dalam peran di masyarakat. Kualitas guru digambarkan oleh Al Abrasy memiliki sifat-sifat, yaitu: zuhud senantiasa berniat mencari keridhaan Allah, bersih (fisik dan psikhisnya), ikhlas dalam bekerja, pemaaf, mencintai murid seperti mencintai anaknya sendiri, memahami tabi'at murid, dan menguasai mata pelajaran. Guru dalam sistem pendidikan Islam adalah diharapkan menjadi orang yang kompromi terhadap sesuatu yang berasal pada pengetahuan secara langsung diperoleh melalui sumber utama. Karena itu, umat Islam dilarang agar tidak berpegang terhadap suatu pendapat yang tidak ada padanya ilmu. Itu artinya, guru dalam Islam harus memiliki kemampuan berpikir original, dan harus diperoleh dan tersusun dalam sumber yang terpercaya. Prinsip ini adalah kualitas utama yang secara langsung menyelidiki lebih dahulu sebelum menyampaikan segala sesuatu kepada siswanya. Itu artinya, guru dalam Islam selain sebagai tugas pengabdian dalam profesinya juga sekaligus adalah ilmuan.

Dalam konteks ini guru dalam pendidikan Islam dalam peranya adalah pribadi yang memiliki komitmen. Semua loyalitasnya tertumpah kepada ideologi Islam dalam kehidupannya. Pengajaran bagi guru tidak hanya profesi untuk kehidupannya. Guru memiliki komitmen untuk menghasilkan generasi muda para pelajar dan juga bertanggung jawab untuk meningkatkan masyarakat Islam. Dengan kata lain, prinsip ini membuat guru adalah pribadi kunci dalam menata pendidikan Islam, dan tugas lainnya meningkatkan kualitas masyarakat Islam dengan memperkuat tujuan moral Islam. 
Sesungguhnya pekerjaan guru tidak hanya mengajar dan melatih pelajar, dalam menata pelajaran yang dipelajari tetapi lebih dari itu guru bertindak sebagai teladan/model untuk menanamkan nilai Islam dalam hati dan jiwa pelajar. Berkenaan dengan penegasan di atas, seorang guru dalam Islam dianggap tidak baik atau gagal untuk memindahkan teori ke dalam pengamalan anak. Sebagai seorang guru PAI diharapkan mengaktualisasikan semua yang diucapkannya. Rasulullah contoh teladan bagi umatnya, termasuk bagi para guru. Seluruh perkataan, perbuatan dan perilaku Rasulullah Muhammad SAW menjadi contoh keutamaan kepribadian bagi semua peran yang ada di muka bumi ini, sesuai kepemimpinan Rasul, sebagai pemimpin, kepala negara dan pemerintahan, sebagai suami, sebagai ayah, ulama, dan panglima perang. Dalam proses pendidikan Islam, Rasulullah menggunakan seluruh strategi pengembangan kepribadian muslim dalam tugas risalahnya. Prinsip dan strategi tilawah (membacakan ayat-ayat Tuhan) yang tertulis/qur'aniyah dan ayat tidak tertulis (yang ada di alam ini), tazkiyah, (pensucian jiwa) dan ta'lim(pembelajaran), dalam melaksanakan tugas risalah harus menjadi misi utama dan kualitas prima yang dituntut ada pada diri guru dalam Islam.

Peningkatan mutu (kualitas) berarti penambahan pengetahuan, pembinaan skil, dan pengembangan keterampilan tentang pelaksanaan tugas mengajar sebagai guru. Dalam konteks zaman yang terus berubah, maka peningkatan kualitas menjadi suatu keniscayaan. Untuk itu sebenarnya diperlukan pengembangan tingkat profesionalitas sehingga profesionalisme yang dimiliki guru-guru pendidikan agama Islam menjadi matang dalam menjawab tantangan pergeseran nilai dan kemajuan teknologi di bidang pendidikan. Karena itu, pengembangan kemampuan profesional guru tidak hanya bagi guru-guru baru dalam tugasnya, akan tetapi dipentingkan pula sekaligus untuk mengembangkan pola karir guru yang menjanjikan antusiasme, pengharapan dan komitmen mereka dalam bertugas sebagai guru.

Keprofesionalan guru (guru yang memiliki kompetensi) saat ini dapat diukur dengan beberapa kompetensi dan berbagai indikator yang melengkapinya, tanpa adanya kompetensi dan indikator itu maka sulit untuk menentukan keprofesionalan guru. Elliot dan Dweck,ed, kompetensi mengakar kepada konsep 
sebagai keterampilan, dan kemampuan seseorang yang berkembang untuk tingkat efektivitas dalam transaksi dengan lingkungan dan untuk keberhasilan tindakan/kinerja seseorang. Kemudian dapat pula didefinisikan bahwa kompetensi adalah sebagai kondisi atau kualitas efektivitas, kemampuan, kecakapan atau keberhasilan.

Kompetensi-kompetensi yang meliputi keprofesionalan guru (berdasarkan Undang-Undang No 14 Tahun 2005, tentang Guru dan Dosen), dapat dilihat dari empat kompetensi, yaitu: (1) Kompetensi Pedagogik, (2) Kompetensi kepribadian, (3) Kompetensi professional, dan, (4) Kompetensi sosial. Keempat komptensi ini memiliki indikator-indikator tertentu yang memberikan jaminan bahwa keempatnya dapat dilaksanakan dan terukur secara kuantitatif dan kualitatif, baik melalui pendidikan pra jabatan, in serving training, diklat tertentu, dan lain sebagainya. Keempat kompetensi di atas, memiliki indikator-indikator, yaitu:

1. Kompetensi pedagogik: Kemampuan dalam pengelolaan pembelajaran peserta didik, indikatornya: a) Pemahaman wawasan atau landasan kependidikan, b) Pemahaman terhadap peserta didik, c) Pengembangan kurikulum/silabus, d) Pemahaman terhadap peserta didik, e) Perancangan pembelajaran, f) Pelaksanaan pembelajaran yang mendidik dan dialogis, g) Pemanfaatan teknologi pembelajaran, h) Evaluasi proses dan hasil belajar, dan, i) Pengembangan peserta didik untuk mengaktualisasikan berbagai potensi yang dimilikinya.

2. Kompetensi kepribadian; pemilikan sifat-sifat kepribadian, indikatornya: a) Berakhlak mulia, b) Arif dan bijaksana, c) Mantap, d) Berwibawa, e) Stabil, f) Dewasa, e) Jujur, f) Menjadi teladan bagi peserta didik dan masyarakat, g) Secara objektif mengevaluasi kinerja sendiri, dan, h) Mau dan siap mengembangkan diri seara mandiri dan berkelanjutan.

3. Kompetensi profesional; kemampuan dalam menguasai pengetahuan bidang ilmu, teknologi, dan/atau seni yang diampunya, indikatornya:

a. Materi pelajaran secara luas dan mendalam sesuai standar isi program satuan pendidikan, mata pelajaran, dan/atau kelompok mata peajaran yang akan diampunya. 
b. Konsep-konsep dan metode disiplin keilmuan, teknologi, atau seni yang relevan yang secara konseptual menaungi atau koheren dengan program satuan pendidikan, mata pelajaran, dan/atau kelompok mata pelajaran yang akan diampu.

4. Kompetensi sosial; dengan indikatornya: a) Berkomunikasi lisan, tulisan, dan/atau isyarat, b) Menggunakan teknologi komunikasi dan informasi secara fungsional, c) Bergaul secara efektif dengan peserta didik, sesama pendidik, tenaga kependidikan, pimpinan satuan pendidikan, orangtua/wali peserta didik, bergaul secara santun dengan masyarakat sekitar dengan mengindahkan norma serta system nilai yang berlaku, dan, d) Menerapkan prinsip-prinsip persaudaraan sejati dan semangat kebersamaan.

Keempat kompetensi profesional yang seharusnya melekat dalam diri para guru itu, bukanlah sesuatu yang mudah untuk diterapkan jika tidak ada kemauan dari berbagai pihak, terutama guru itu sendiri. Namun, hal itu akan menjadi mudah diterapkan, jika kemauan dari berbagai pihak, terutama guru itu sendiri memiliki komitmen untuk mencapai keprofesionalan, sebagai bagian dari tanggung jawab kepada diri sendiri, kepada peserta didik, kepada pemangku kepentingan, dan yang tak kalah pentingnya, adalah tanggung jawab kepada Allah SWT, yang telah memberikan amanah kepada setiap guru untuk dapat melaksankan tugas dan fungsi sebagai pendidik, pengajar, pembimbing, dan pelatih.

Keprofesionalan guru Pendidikan Agama Islam pada Sekolah Umum dan Madrasah, perlu dikemukakan kompetensi yang harus dimilikinya, yaitu:

\section{Kompetensi Utama}

a. Kemampuan Akademik

Pengetahuan yang dimiliki oleh seorang guru agama Islam pada sekolah umum harus mendalam terutama meliputi hal-hal berikut:

1) Memahami dengan baik tujuan agama Islam (maqashid al-syari'ah)

2) Memahami dengan baik dasar-dasar sosiologi dan psikologi pendidikan Islam dan umum

3) Memahami karakter dan perkembangan psikologis, sosiologis dan akademik setiap pelajar 
4) Memahami cara mengembangkan kecerdasan intelektual, emosional dan spiritual anak didik

5) Memahami kurikulum yang berlaku secara utuh, terutama menyangkut mata pelajaran yang menjadi bidang tugasnya

6) Memahami relevansi bidang studi yang diajarkan dengan ajaran-ajaran keislaman, atau sebaliknya

7) Memahami metode pembelajaran yang paling tepat dan mutakhir

8) Memahami perencanaan, proses, dan evaluasi belajar yang tepat

9) Memahami cara memanfaatkan jam belajar yang terbatas, memilah bahan ajar yang membutuhkan pertemuan langsung atau cukup dengan penugasan, secara efektif

10) Memahami cara menggunakan alat bantu (teknologi) dan sumber belajar secara tepat

11) Memahami tujuan pendidikan dan pengajaran

12) Memahami tujuan pendidikan nasional

13) Memahami tujuan khusus pendidikan Agama pada sekolah umum untuk setiap jenjang (SD, SLTP, dan SMU).

\section{b. Kemampuan Profesional}

Beberapa jenis kemampuan yang perlu dimiliki oleh uru PAI pada sekolah umum di atas bukan hanya dalam tataran teori tapi juga praktek. Dalam hal ini secara rinci guru-guru diharapkan mampu mempraktekkan hal-hal berikut:

1) Menciptakan lingkungan sekolah yang saling menghormati dan memahami juga dengan penganut agama lain

2) Menanamkan agar siswa memberi penghargaan yang tinggi terhadap ilmu dan belajar termasuk pelajaran agama

3) Membiasakan perilaku dan sikap yang sopan kepada yang lain

4) Menumbuhkan sikap positif seperti tekun (sabar), menghargai dan menerima diri dan tegar terhadap kenyataan yang dialami (tawakkal) dan berpikir positif (husnuzzon)

5) Membiasakan anak didik menjaga kebersihan dan merawat kepentingan umum 
6) Mengembangkan perilaku tepat waktu dan memenuhi janji

7) Membangun hubungan emosional yang erat antara siswa dan sekolah

8) Menciptakan suasana sekolah agar menjadi tempat yang nyaman bagi siswa

9) Berkomunikasi dengan bahasa Indonesia yang baik, jelas, dan tepat

10) Menggunakan berbagai pendekatan dalam pengajaran

11) Melibatkan siswa secara maksimal dalam proses pembelajaran

12) Memberi perhatian kepada setiap siswa dengan baik, serta mengevaluasi proses dan pekembangan belajar mereka

13) Menunjukkan sikap mudah dihubungi, tidak kaku (fleksibel), dan bertanggungjawab.

\section{Kompetensi Pendukung}

a. Kemampuan Membangun Hubungan/Komunikasi

Guru PAI yang baik adalah guru yang mampu mengembangkan kemampuan profesionalnya secara terus menerus (ongoing self-development). Kemampuan mengembangkan diri meliputi:

1) Mengambil inisiatif dalam mengembangkan kemampuan diri tanpa perlu menunggu instruksi atasan

2) Menyediakan waktu untuk membaca dan mempelajari metode mengajar terkini

3) Melakukan refleksi dan riset sederhana terhadap pengajaran mereka sendiri secara berkala

4) Mengikuti pelatihan-pelatihan atau pertemuan-pertemuan nonformal tentang pendidikan

5) Melakukan dialog-dialog informal untuk berbagi pengalaman dengan sesame guru

6) Memberi bantuan baik secara langsung maupun tertulis kepada guru-guru lain

7) Mendorong sesama guru dan tenaga kependidikan lainnya untuk melakukan kerja kolektif dalam memberi masukan bagi perbaikan pengajaran dan praktek keagamaan di seolah. 
Selama ini persekolahan hanya dipandang sebagai tempat untuk memberi orang tahu dari tidak tahu. Padahal lebih dari itu, persekolahan merupakan proses terjadinya pendidikan, pengajaran, bimbingan, dan pelatihan yang berlangsung secara simultan. Keempat proses itu (pendidikan, pengajaran, bimbingan, dan pelatihan) berlangsung ketika anak berinteraksi dengan personil sekolah (terutama guru), karena gurulah yang memiliki otoritas dalam melaksanakan pendidikan, pengajaran, bimbingan dan pelatihan di sekolah.

Secara manajerial dan psikologis peningkatan kualitas profesionalisme guru merupakan keniscayaan. Untuk meningkatkan kualitas profesionalisme guru PAI, maka ada beberapa hal yang dapat dilakukan, yaitu: (1) mengikuti pendidikan lanjutan; dari S1/D IV mengikuti pendidikan profesi atau pendidikan lanjutan S2, (2) pelatihan keterampilan kependidikan/pembelajaran, (3) mengikuti workshop kurikulum pembelajaran, (4) mengikuti pelatihan media pembelajaran, (5) mengikuti pelatihan strategi pembelajaran aktif, (6) pemantapan gugus mutu melalui ekstensifikasi MGMP, (7) pelatihan penelitian tindakan kelas, dan (8) pembinaan mental keagamaan, atau soft skills.

Guru sebagai jabatan professional memerlukan pendidikan lanjutan dan latihan khusus (advanced education and special training). Dalam konteks ini guru sebagai jabatan professional seperti dokter dan lawyer memerlukan pendidikan pasca sarjana. Pelatihan untuk peningkatan mutu profesionalisme guru PAI, dapat dilakukan dengan pendekatanon the job training, dan off the job training. Dijelaskan Mukhtar, kegiatan pelatihan dalam bentuk on the job training merupakan internship yang diselenggarakan di dalam kelas maupun di rumah masing-masing, pada universitas untuk membangun metoda pembelajaran dan pelatihan. Dengan system magang terdapat kegiatan untuk memperoleh pengalaman praktis yang digunakan untuk mempelajari sesuatu yang lebih tinggi. Magang juga metode pelatihan di tempat kerja yang berkaitan dengan pengajaran dalam kelas. On the job training dapat diberikan oleh rekan kerja atau supervisor atau bias juga diberikan oleh orang yang ahli dalam pengetahuan dan pekerjaan baik dari perguruan tinggi maupun pusat pelatihan. Sedangkan off the job training merupakan kegiatan pelatihan yang diselenggarakan di luar tempat bekerja. 
Pelatihan untuk mengembangkan kemampuan professional guru dapat dilakukan melalui berbagai jenis dan focus pelatihan. Untuk itu, peran kepala sekolah, supervisor, dan Dinas Pendidikan dan Kebudayaan, atau Kantor Kementerian Agama Kabupaten/Kota, serta Balai Diklat Keagamaan menjadi wahana yang sangat menentukan pencapaian standar kualitas profesionalisme guru yang diharapkan. Selain itu, peran strategis Lembaga Pendidikan Tenaga Kependidikan (LPTK) dalam tugas pengembangan yang dilakukannya juga selalu diberikan amanah pengembangan program Latihan Peningkatan Kualitas Guru (PKG) bagi guru-guru mata pelajaran Pendidikan Agama Islam. Pelatihan peningkatan kualitas guru dimaksudkan untuk mamantapkan profesionalisme guru PAI sehingga kompetensi sebagaimana yang disyaratkan bagi guru dapat terpenuhi untuk mengelola pembelajaran secara maksimal.

\section{KESIMPULAN}

Peningkatan mutu profesionalisme guru PAI sangat tergantung pada proses pembinaan guru dalam jabatan dan di luar jabatan. Setidaknya yang perlu ditingkatkan adalah efektivitas manajemen pendidikan pada tingkat makro, messo, dan mikro di sekolah untuk memfasilitasi guru PAI dapat memaksimalkan kompetensinya sehingga mutu guru PAI benar-benar sesuai dengan harapan stakeholders pendidikan. Fokus pada pendidikan lanjutan, pelatihan, dan pembinaan guru yang sistemik dapat mempercepat peningkatan profesionalisme guru PAI sesuai keperluan dan dinamika pendidikan yang harus dipatuhi. 


\section{DAFTAR PUSTAKA}

Abdurrahman, Hafidz. 2008. Membangun Kepribadian Pendidik Umat. Jakarta: Wadi Press.

Ahmed, Shabir, Anas Abdul Muntaqim, Abdul Satar. 1999. Islam dan Ilmu Pengetahuan. Al-Izzah.

Al-Baghdadi, Abdurrahman. 1996. Sistem Pendidikan di Masa Khilafah Islam AlIzzah.

Arifin. 2000. Psikologi Dahwah; Suatu Pengantar. Jakarta: Bumi Aksara.

Fuad Yusuf, Choirul. 2007. Inovasi Pembelajaran Pendidikan Agama Islam (SMP). Jakarta: PT. Pena Citasatria.

Kholid Fathoni, Muhammad. 2005. Pendidikan Islam dan Pendidikan Nasional [Paradigma baru]. Jakarta: Depag RI.

Muhaimin. 2003. Wacana Pengembangan Pendidikan Islam. Surabaya: PSAPM

Undang-Undang Nomor 14 tahun 2015. 